\title{
GC-MS Analysis and Antimalarial Activity of Methanolic Leaf Extract of Carica papaya against Plasmodium berghei NK65 Infection in Swiss Mice
}

\author{
Johnson Oshiobugie Momoh ${ }^{1^{*}}$, Olanrewaju Anthony Damazio ${ }^{2}$ \\ and Omolayo Monsurat Oyegbami ${ }^{3}$ \\ ${ }^{1}$ Department of Chemical Sciences (Biochemistry Unit), School of Pure and Applied Sciences, \\ Lagos State Polytechnic, Ikorodu, Lagos, Nigeria. \\ ${ }^{2}$ Department of Chemical Sciences (Chemistry Unit), School of Pure and Applied Sciences, \\ Lagos State Polytechnic, Ikorodu, Lagos, Nigeria. \\ ${ }^{3}$ Department of Biological Sciences (Microbiology Unit), School of Pure and Applied Sciences, \\ Lagos State Polytechnic, Ikorodu, Lagos, Nigeria.
}

Authors' contributions

This work was carried out in collaboration among all authors. Author JOM designed the methodology and study, wrote the protocol and the first draft of the manuscript and contributed to the discussions and corrections. Author OAD explained the interpretation of the AAS, GC-MS and the medicinal functions of the phytocomponents found in the plant. Authors JOM and OMO carried out the laboratory analyses. Author JOM was involved in the collation of data and statistical analysis. All authors read and approved the final manuscript.

Article Information

DOI: $10.9734 / A R R B / 2020 / v 35 i 1230323$

Editor(s):

(1) Dr. Viduranga Y. Waisundara, Australian College of Business and Technology, Sri Lanka.

(1) Debleena Roy, Lady Brabourne College (LBC), India.

(2) Paramesh H, Debre Berhan University, Ethiopia.

(3) R. Suja Pandian, Bharathidasan University (BDU), India Complete Peer review History: http://www.sdiarticle4.com/review-history/60062

Original Research Article

Received 02 June 2020

Accepted 08 August 2020

Published 31 December 2020

\section{ABSTRACT}

Aim: The study determines the GC-MS and the anti-malarial activity of methanolic leaf extract of Carica papaya in Swiss mice infected with Plasmodium berghei NK65.

Study Design: The experimental study lasted for five weeks.

Place of Study: Department of Chemical Sciences (Biochemistry Unit) and animal House unit in Department of Biological Sciences (Environmental Biology Unit), School of Pure and Applied 
Sciences, Lagos State Polytechnic, Ikorodu, Lagos, Nigeria.

Study Design and Methodology: AAS, GC-MS and phytochemical analyses were determined in the plant extract using standard procedures. Thirty-six Swiss mice of both sexes (26-32g) were divided into six groups of six mice each. Group A (normal control) was untreated and uninfected. Groups B-F were intraperitoneally inoculated with $P$. berghei NK65, while group B (disease control) was untreated-infected group, group $C$ and $D$ (standard drugs) received standard drugs, chloroquine $(10 \mathrm{mg} / \mathrm{kg} \mathrm{B.WT})$ and artesunate $(10 \mathrm{mg} / \mathrm{kg} \mathrm{B.WT})$; groups $E$ and $F$ received methanolic leaf extract of C. papaya at 400 and $600 \mathrm{mg} / \mathrm{kg}$ B.WT respectively. WBC, HCT and HGB were determined in the whole blood using BC-3200 Auto Hematology Analyzer. MDA, TP, SOD \% inhibition, SOD unit, CAT and GSH were all determined in the liver homogenate using standard procedures.

Results: The AAS analysis shows that the extract contains minerals like: potassium, calcium, magnesium, iron and sodium. Twenty-six compounds were identified to be present in the extract using GC-MS analysis. The active compounds with their retention time, molecular weight, molecular formula, peak area and activities were predicted. The three major prevailing compounds and their percentage abundance are: squalene (27.28\%), neophytadiene (12.71\%) and phytol $(10.16 \%)$ respectively. The phytochemical analysis indicates the presence of tannins, saponins, alkaloids, phenolic compounds etc. The C. papaya extract caused $56.76 \%$ and $75.53 \%$ significant $(P<0.05)$ reduction in parasitemia at 400 and $600 \mathrm{mg} / \mathrm{kg}$ body weight respectively while chloroquine exerted $92.86 \%$ and artesunate exerted $90.67 \%$ reduction at $10 \mathrm{mg} / \mathrm{kg}$ body weight respectively carried out during curative test. The extract significantly $(P<0.05)$ reduced WBC count and increase HGB and $\mathrm{HCT}$ concentration in the treated mice compared to the infected untreated mice. There were significant $(p<0.05)$ increase in the TP, SOD \% inhibition, SOD unit, GSH and CAT levels in the liver homogenate of animals treated with chloroquine, artesunate and extract of $C$. papaya compared to the untreated mice. MDA level was significantly decreased in the malaria treated mice compared to the untreated mice.

Conclusions: The study shows that methanolic leaf extract of Carica papaya possess antimalarial activity in Swiss mice infected with Plasmodium berghei NK 65.

Keywords: Carica papaya; anti-malarial activity; GC-MS; Plasmodium berghei NK 65; Swiss mice; biochemical parameters.

\section{INTRODUCTION}

Malaria is an infectious disease, caused by different protozoan parasites of the genus Plasmodium [1]. Study has shown that Plasmodium are resistance to antimalarial drugs, which leads to drug failure, new drugs production or the use of drug combinations for the treatment of malaria infections using traditional medicinal plants [2]. Malaria is the leading cause of illness and death in sub-Saharan Africa with an annual mortality of approximately one million children under five [3].

Carica papaya Linn. (family: Caricaceae) is primarily cultivated for its fruit. Different parts of the plant have been used in traditional medicine to treat various diseases. The juice of the leaves is taken to treat malarial fever [4]. Ethyl acetate crude leaves extract of $C$. papaya showed high antiplasmodial activity against Plasmodium falciparum and $P$. falciparum-resistant strains [5]. The ethanolic extract of $C$. papaya leaves showed potential as a source of drugs against urinary tract microbes [6]. The aqueous extract of the leaves exhibited the ability to inhibit tumor cell lines [7] and this activity was potentiated with phenolic compounds [8,9]. The aqueous extract of $C$. papaya also showed significant protective effect against alcohol induced oxidative damage to the gastric mucosa in rats [10], and it was effective in healing induced wound in rats [11]. The seed and fruit of $C$. papaya showed bacteriostatic activity against several enteropathogens in human [12]. The root of $C$. papaya plant is used to treat urinary disorders while the bark is used to treat toothache [13]. The present study indicate the GC-MS analysis and antimalarial activity of methanolic leaf extract of Carica papaya against Plasmodium berghei NK65 infection in Swiss mice

\section{MATERIALS AND METHODS}

\subsection{Collection and Identification of Plant}

The leaves of Carica papaya was obtained from Lagos State Polytechnic Ikorodu in Lagos, Nigeria. Authentication of the plant was done in the Department of Biological Sciences 
(Environmental Biology Unit) School of Pure and Applied Sciences, Lagos State Polytechnic, Ikorodu, Lagos, Nigeria.

\subsection{Mineral Analysis of Methanolic Leaves Extract of Carica papaya}

$2 \mathrm{~g}$ of dried C. papaya leaves was digested with $10 \mathrm{ml}$ of aqua regia $\left(\mathrm{HNO}_{3}\right.$ and $\mathrm{HCl}$ in the ratio $1: 3)$ and the mixture was heated on porcelain crucible until the brown fumes disappeared leaving white fumes. It was later filtered with whatman filter paper into universal bottle. The mineral elements in the sample were determined by Atomic Absorption Spectrophotometer (Model Perkin Elmer AAnalyst 400).

\subsection{Gas Chromatography-Mass Spectrometry (GC-MS) Analysis of Methanolic Leaf Extract of Carica papaya}

GC-MS analysis of the plant extract was carried out on an Agilent technology 7890 GC system equipped with a mass spectrometric detector (MSD) as described by Momoh et al. [14]

\subsection{Detection of Components}

Analysis of mass spectrum GC-MS was conducted by the database of National Institute Standard and Technique (NIST) which contained more than 62,000 patterns. The spectrum of the unidentified compound was compared with the spectrum of the identified compounds stored in the National Institute Standard and Technique library. The names, molecular weight, structure of the compounds in the test material were ascertained.

\subsection{Preparation of Carica papaya Methanolic Leaf Extract}

The Carica papaya leaves were washed with water to remove dirt, air dried under shade in the laboratory, pulverised into coarse power using industrial machine. Extraction was carried out by dispersing $200 \mathrm{~g}$ of the grounded C. papaya leaves into 2 Litres of $80 \%$ methanol at room temperature $\left(25 \pm 2{ }^{\circ} \mathrm{C}\right)$ and shaked for 72 hours. The solution was filtered by passing through cotton and the resultant filtrate was concentrated with the help of rotary evaporator at a temperature not exceeding $40^{\circ} \mathrm{C}$. The concentrated extract was later dried to complete dryness in an aerated oven at $40^{\circ} \mathrm{C}$ for 48 hours. The concentrate was later stored in a refrigerator at $4^{\circ} \mathrm{C}$.

\subsection{Qualitative Phytochemical Analysis of Carica papaya Leaf Extract}

Phytochemical analyses for phytochemical constituents were carried out on the C. papaya leaf extract using standard procedures $[15,16]$.

\subsection{Experimental Animals}

All the Swiss mice of both sexes used have a weight ranging from 26 to 32 gram. They were obtained from University of Lagos, Nigeria. They were acclimatized for seven days to experimental laboratory condition of $23 \pm 2^{\circ} \mathrm{C}$. They were kept in cages and fed with commercial rodent chow and supply with water ad libitum. The mice were used in accordance with $\mathrm{NIH}$ guide for the care and use of laboratory animals; NIH Publication revised, (1985) [17].

\subsubsection{Malaria parasites}

Plasmodium berghei NK65 is chloroquinesensitive and was used to assess the antimalarial activity of $C$. papaya methanolic leaf extract. The parasite was obtained from National Institute for Medical Research (NIMR) Lagos, Nigeria. The parasites were maintained by continuous re-infestation in mice.

\subsubsection{Inocula}

Parasitized red blood cells were obtained from a donor infected mouse by ocular puncturing. This was prepared by determining percentage parasitemia and the red blood cells count of the donor mouse and diluting them with normal saline in proportions indicated by both determinations [18]. Each mouse was inoculated intraperitoneally with infected red blood suspension $(0.2 \mathrm{~mL})$ containing $1 \times 10^{7} P$. berghei NK65 parasitized erythrocyte.

\subsubsection{Grouping of animals}

Group A (Normal control): Healthy Swiss mice

Group B (Disease control): mice infected with P.berghei NK65 received no treatment

Group C (Positive control I): Infected mice that received $10 \mathrm{mg} / \mathrm{kg} \mathrm{B.WT}$ of chloroquine (CQ) 
Group D. (Positive control II): Infected mice that received $10 \mathrm{mg} / \mathrm{kg} \mathrm{B.WT}$ of Artesunate

Group E: Infected mice that received $400 \mathrm{mg} / \mathrm{kg}$ B.WT of $C$. papaya methanolic leaf extract

Group F: Infected mice that received $600 \mathrm{mg} / \mathrm{kg}$ B.WT of C. papaya methanolic leaf extract

\subsubsection{In vivo antiplasmodial activities Curative (Rane's) test}

Thirty Swiss mice weighing between 26 and 32 gram were injected intraperitonealy with standard inocula of $P$. berghei NK65 containing $1 \times 10^{7}$ infected red blood cells. Seventy-two hours later, the mice were randomly divided into 5 groups of 6 mice per group as shown above. Group A mice were not induce with $P$. berghei NK65. All treatments were administered orally. Treatment continued daily until the seventh day when thin films were made from the tail blood of each mouse. The films were fixed with methanol, stained with Giemsa and parasitemia density examined by microscopically counting the parasitized red blood cells on at least 1000 red blood cells in 10 different fields [19,20].

1. $\%$ parasitemia $=\frac{\text { No.of parasitized } R B C}{\text { Total no.of } R B C \text { counted }} \times 100$

2. Percentage suppression of parasitemia was calculated:

$\frac{\text { Parasitemia of negative control }- \text { parasitemia of test }}{\text { Parasitemia of negative control }} \times 100$

\subsubsection{Collection of blood samples}

The experimental mice were sacrificed by cervical decapitation after 24 hours of fasting. Blood were collected from the animals by ocular puncture into EDTA tubes for the determination of hematological parameters. The animals were dissected while their livers were excised for biochemical examinations.

\subsubsection{Hematological analysis}

The bloods in the EDTA tubes were assayed for hematological parameters using BC-3200 Auto Hematology Analyzer in Central Research Laboratory in Lagos University Teaching Hospital Lagos, Nigeria. The hematological parameters investigated were White blood cell count (WBC), Hemoglobin (HGB) and hematocrit (HCT) counts.

\subsubsection{Preparation of liver homogenate}

The liver tissues of some of the sacrificed animals were removed and the liver samples were cut into pieces and homogenized with phosphate buffer saline (PBS) to give a $10 \%$ $(w / v)$ liver homogenate. The liver homogenates were then centrifuged at $12,000 \mathrm{rpm}$ for 60 minutes. The supernatant obtained was later used for the assay of total protein, catalase, MDA, GSH, SOD\% inhibition and SOD unit.

\subsubsection{Determination of total protein}

Total protein (TP) was determined in the liver homogenate using Randox diagnostic kits.

\subsubsection{Determination of catalase (CAT)}

The liver homogenate was assayed for catalase colorimetrically at $620 \mathrm{~mm}$ and expressed as $\mu$ moles of $\mathrm{H}_{2} \mathrm{O}_{2}$ consumed $/ \mathrm{min} / \mathrm{mg}$ protein by the method of Rukkumani et al. [21]

\subsubsection{Determination of Lipid Peroxidative (LPO) indices}

Lipid peroxidation as evidenced by the formation of TBARS was measured in the liver homogenate by the method of Jiang et al. [22]

\subsubsection{Determination of Superoxide Dismutase (SOD)}

The SOD activity was estimated by its capacity of inhibiting pyrogallol autooxidation in alkaline medium. The liver homogenate was assayed for the presence of SOD\% by utilizing the technique described by Zou et al. [23]

\subsubsection{Determination of Reduced Glutathione (GSH)}

Reduced glutathione (GSH) was determined in the liver homogenate using the method of Rukkumani et al. [21].

\subsection{Statistical Analysis}

The data were expressed as mean \pm SD and parasitemia of the different groups were assessed by unpaired student t-test using Graphpad prism Instat Demo version 5.01. Comparisons were done using one way analysis of variance (ANOVA) complemented with Bonferroni's to compare all pair of columns. For 
all the analyses, a $\mathrm{P}<0.05$ was considered statistically significant.

\section{RESULTS}

\subsection{Mineral Analysis of Carica papaya Leaves}

Table 1 below shows the percentage composition of minerals in the leaves of $C$. papaya

\subsection{GC-MS Analysis of Methanolic Leaf Extract of C. papaya}

The GC-MS analysis of methanolic leaf extract of C. papaya showed that the extract contains 26 compounds with 3 major prominent compounds (Table 2).

\subsection{Phytochemical Result}

The Phytochemicals shows the result of qualitative phytochemical composition of methanol leaf extract of Carica papaya. The results revealed the presence of alkaloids, cardiac glycosides anthraquinones, tannins, reducing sugar, flavonoids, saponins, terpenoids and phenolic compounds as shown in Table 3.

\subsection{Antiplasmodial (Curative) Test}

The mean parasitemia density and percentage suppression of Plasmodium berghei NK65 in infected mice treated with standard drugs and methanolic leaf extract of Carica papaya are shown in Table 4. The percentage suppression of infected mice treated respectively with choloroquine, arthesunate, 400 and $600 \mathrm{mg} / \mathrm{kg}$ body weight of leaf extract of Carica papaya significantly $(P<0.05)$ reduced when compared with infected mice without treatment (group B). The result shows that the plant is more active at a dose of $600 \mathrm{mg} / \mathrm{kg}$ body weight by having a percentage suppression of $75.53 \%$.

\subsection{Complete Blood Count (CBC)}

The graph below shows that there were significant increase $(P<0.05)$ in HGB concentration in the healthy and treated mice (group C-F) compared to the infected untreated mice (group B). HCT concentration was significantly lowered $(P<0.05)$ in group $B$ mice compared to mice in other groups. WBC count was significantly $(P<0.05)$ high in the group $B$ mice compared to mice in other groups.

\subsection{Antioxidant and Oxidative Stress Parameters}

Fig. 3 below shows that total protein and reduced glutathione were significantly $(P<0.05)$ increased while MDA values are decreased in the healthy and treated group mice (group A, C-F) compared to the infected untreated mice (group $B$ ).

Fig. 4 shows that there were significant increase $(P<0.05)$ in catalase, SOD \% inhibition and SOD (unit) concentration in the healthy and treated mice compared to the infected untreated mice (group B).

\section{DISCUSSION}

Medicinal plants used in the treatment of infectious diseases contain active phytochemicals some of which are responsible for the plants' characteristic odors, color and pungencies while others are used as food and medicinal [44].

The data from Table 1 shows that $C$. papaya leaves contain elements like $\mathrm{K}, \mathrm{Na}, \mathrm{Mg}, \mathrm{Ca}$ and $\mathrm{Fe}$ in various proportions $(\mathrm{Ca}>\mathrm{Mg}>\mathrm{K}>\mathrm{Fe}>$ $\mathrm{Na}$ ). The result shows that $\mathrm{Ca}$ content is the highest in the leaves of C. papaya. Different research works have shown the present of minerals in C. papaya leaf $[45,46]$. Study has shown that high amount of potassium in the body increase iron utilization [46] and it helps to control hypertension through body fluid [46]. Sodium ion is present in outside cells and is one of the primary electrolytes responsible for maintaining fluid balance [46]. Magnesium is an essential element that is used by plants in relatively large amounts and its deficiency can affect virtually every organ system of the human body [45]. Calcium is essential for healthy teeth, bones and blood [45]. Deficiency of Fe causes anemia [45].

For the quantitative determination of compounds, gas chromatography with flame ionization detector (GC-FID) and GC-MS are usually preferred. The different compounds identified with their functions from each of the mass spectra fragmentation patterns are listed in Table 2. A total of 26 compounds were identified consisting of three (3) major compounds and twenty-three (23) minor compounds. The three prominent compounds constitute $50.15 \%$ of the $C$. papaya extract. The three major compounds and their percentage abundance are Squalene (27.28\%), Neophytadiene (12.71\%) 
and Phytol (10.16\%) respectively. These prominent compounds were represented by peaks 24,7 and 16 with retention times of $31.010,14.330$ and 18.832 respectively. The activities of some of the compounds have been reported in Table 2 . The most prominent compound in the extract of $C$. papaya was squalene. Squalene is a natural lipid that belongs to the terpenoid family and a precursor of cholesterol biosynthesis. It is extensively used as an excipient in pharmaceutical formulations for disease management and therapy [42]. Squalene acts as a protective agent and has been shown to decrease chemotherapy-induced side-effects and exhibits chemopreventive activity [42]. It is a weak inhibitor of tumor cell proliferation; it contributes to the treatment of cancer due to its potentiation effect. It enhances the immune response to various associated antigens. Squalene is well absorbed orally and has been used to improve the oral delivery of therapeutic molecules [42]. Ruba and Mohan, [41] study shows that squalene is a good antibacterial, cancer preventive, antioxidant, antitumor, chemo preventive, immunostimulant and lipoxygenaseinhibitor. Mostafa et al. [29] study shows that squalene is used for gastrin inhibitor, histamine release inhibitor, sugar-phosphatase inhibitor, anti-inflammatory, antihelmintic and antiparasitic. In another study carried out by Ezhilan and Neelamegam, [47], it was observed that squalene has anti-oxidant, anti-tumor, anticancer, chemo-preventive, pesticidal and sunscreen properties. Squalene is used to neutralize different xenobiotics, it has anti-inflammatory, anti-atherosclerotic and anti-neoplastic, it plays a role in skin aging and pathology and possess adjuvant activities [28]. The second most prominent compound in the extract was neophytadiene and it is used as antioxidant, analgesic, antimicrobial, antipyretic, and antiinflammatory activities [28]. Mostafa et al. [29] study shows that neophytadiene is used for histamine release inhibitor, carminative, gastrin inhibitor, antiulcerative, antiprotozoal (Leishmania) and possess anti-parasitic properties. The third abundant compound in the methanolic leaf extract of $C$. papaya was phytol. Phytol is an acyclic diterpene alcohol it is used as a precursor for the manufacture of synthetic forms of Vitamin $E$ and vitamin $K$. It has anticancer, antimicrobial, and antiinflamatory activities. It is also used as diuretic [37]. Mostafa et al. [29] study shows that phytol is used as histamine release inhibitor, lipid metabolism regulator, antihelmintic, antiparasitic, antiprotozoal, (leishmania) and spasmolytic.
Phytol treatments deceases the autoimmune response and ameliorate both acute and chronic phases of arthritis [48]. In a study carried out by Venkata et al. [28], it was stated that phytol has antimicrobial, anticancer, anti-diuretic, antiinflammatory, immunostimulatory and antidiabetic properties.

The minor identified constituents in the plant extract also possess biological activity or may act in synergy to reduce parasite load. nHexadecanoic acid functions as inhibitor of phospholipase A2 [34]; hence, it is an antiinflammatory compound used for the treatment of rheumatic symptoms in traditional medical system [34]. Delta.-Tocopherol is an isomer of vitamin $E$. Vitamin $E$ is a family of eight natural compounds (four tocopherols ( $\alpha, \beta, \gamma$, and $\delta-$ ) and four tocotrienols ( $\alpha, \beta, \gamma$, and $\delta-)$ ) with different antioxidant and biological activities [43]. Vitamin $\mathrm{E}$ is the major lipid-soluble component in the cell antioxidant defence system and is entirely obtained from diet. The most active form of this vitamin is a-tocopherol, which is widely distributed in nature and it is often used in vitamin supplements [43]. It has various important roles within the body because of its antioxidant activity. Oxidation reaction has been linked to various possible diseases conditions, including diabetes, cancer, ageing, asthma, arthritis and cataracts. Vitamin $E$ has been shown to be effective in preventing or ameliorating the effect of these diseases [43]. It helps to reduce the production of prostaglandins such as thromboxane, which causes platelet clumping [43]. Mono (2-ethylhexyl) phthalate (MEHP) stimulated basal steroidogenesis associated with up-regulation of StAR protein expression with no effect on hCG-stimulated androgen production by LCs from CBA/Lac and C57BL/6j mouse genotypes [40]. MEHP attenuated ATP production and increased superoxide generation by both phenotypes of mouse LCs that indicated mitochondrial dysfunction induced by the monophthalate [40].

This study revealed the presence of important phytochemicals like saponins, reducing sugar, alkaloids, terpenoids, tannins, anthraquinones, flavonoids, cardiac glycosides and phenolic compounds in the methanolic leaf extract of Carica papaya. The study is in line with the reports of a number of authors that showed that active phytochemicals like: phenolics, alkaloids, steroids, saponins, phlabotannins, amino acids, flavonoids etc are present in the different extract of Carica papaya [49-51]. Studies have shown 
Table 1. Mineral constituents of Carica papaya leaves

\begin{tabular}{|c|c|c|c|c|c|}
\hline Plant & $\mathrm{K}(\mathrm{mg} / 100 \mathrm{~g})$ & $\mathrm{Ca}(\mathrm{mg} / 100 \mathrm{~g})$ & $M g(m g / 100 g)$ & Fe $(\mathrm{mg} / 100 \mathrm{~g})$ & $\mathrm{Na}(\mathrm{mg} / 100 \mathrm{~g})$ \\
\hline C. papaya & $10.1531 \pm 0.0050$ & $38.2392 \pm 0.001$ & $15.1608 \pm 0.002$ & $0.23218 \pm 0.003$ & $0.03286 \pm 0.0050$ \\
\hline
\end{tabular}

Table 2. Phytocomponents identified in the leaf of Carica papaya using GC-MS

\begin{tabular}{|c|c|c|c|c|c|c|}
\hline $\begin{array}{l}\text { PK } \\
\text { no }\end{array}$ & $\begin{array}{l}\text { Retention } \\
\text { time }\end{array}$ & Name of compound & $\begin{array}{l}\text { Molecular } \\
\text { formulae }\end{array}$ & $\begin{array}{l}\text { Molecular } \\
\text { weight } \\
\text { (g/mol) }\end{array}$ & $\begin{array}{l}\text { Peak } \\
\text { area (\%) }\end{array}$ & Activity \\
\hline 1 & 10.131 & $\begin{array}{l}\text { 2(4H)-Benzofuranone, } 5,6,7,7 a- \\
\text { tetrahydro -6-hydroxy-4,4,7a-trimethyl- }\end{array}$ & $\mathrm{C}_{11} \mathrm{H}_{16} \mathrm{O}_{3}$ & 196.24 & 1.12 & Antimicrobial [24]. \\
\hline 2 & 10.909 & 3-Trifluoroacetoxypentadecane & $\mathrm{C}_{17} \mathrm{H}_{31} \mathrm{~F}_{3} \mathrm{O}_{2}$ & 324.4 & 1.19 & Anti-nephrotoxic and antioxidant activities [25]. \\
\hline 3 & 11.555 & $\begin{array}{l}\text { cis-2,5-Dimethoxy-4-ethoxy-.beta.- } \\
\text { methylstyrene }\end{array}$ & $\mathrm{C}_{13} \mathrm{H}_{18} \mathrm{O}_{3}$ & 222.28 & 0.85 & NF \\
\hline 4 & 12.871 & 4-Heptafluorobutyryloxyhexadecane & $\mathrm{C}_{20} \mathrm{H}_{33} \mathrm{~F}_{7} \mathrm{O}_{2}$ & 438.5 & 1.13 & NF \\
\hline 5 & 13.644 & $\begin{array}{l}\text { 6-Hydroxy-4,4,7a-trimethyl-5,6,7,7a - } \\
\text { tetrahydrobenzofuran-2(4H)-one }\end{array}$ & $\mathrm{C}_{11} \mathrm{H}_{16} \mathrm{O}_{3}$ & 196.2429 & 2.53 & $\begin{array}{l}\text { Antidiabetes[26]. Anti-inflammatory response } \\
\text { [27]. }\end{array}$ \\
\hline 6 & 13.718 & Cyclotetradecane & $\mathrm{C}_{14} \mathrm{H}_{28}$ & 196.37 & 2.20 & $\mathrm{NF}$ \\
\hline 7 & 14.330 & Neophytadiene & $\mathrm{C}_{20} \mathrm{H}_{38}$ & 278.5 & 12.71 & $\begin{array}{l}\text { Antioxidant, analgesic, antimicrobial, antipyretic, } \\
\text { and anti-inflammatory activities [28]. Histamine } \\
\text { release inhibitor, carminative, gastrin inhibitor, } \\
\text { antiulcerative, antiprotozoal (Leishmania) and } \\
\text { possess anti-parasitic properties [29]. }\end{array}$ \\
\hline 8 & 14.433 & 2-Pentadecanone, 6,10,14-trimethyl & $\mathrm{C}_{18} \mathrm{H}_{36} \mathrm{O}$ & 268.4778 & 2.15 & $\begin{array}{l}\text { Allelopathic and antibacterial [30], Antibacterial } \\
\text { [31]. }\end{array}$ \\
\hline 9 & 14.657 & cis-5-Decen-1-yl acetate & $\mathrm{C}_{12} \mathrm{H}_{22} \mathrm{O}_{2}$ & 198.302 & 1.04 & $\mathrm{NF}$ \\
\hline 10 & 14.891 & 1-Methoxy-3-(2hydroxyethyl)- nonane & $\mathrm{C}_{12} \mathrm{H}_{26} \mathrm{O}_{2}$ & 202.33 & 2.09 & NF \\
\hline 11 & 15.452 & Trans-Farnesol & $\mathrm{C}_{15} \mathrm{H}_{26} \mathrm{O}$ & 222.3663 & 1.74 & NF \\
\hline 12 & 15.544 & Hexadecanoic acid, methyl ester & $\mathrm{C} 17 \mathrm{H} 34 \mathrm{O} 2$ & 270.451 & 6.14 & $\begin{array}{l}\text { Antioxidant, antimicrobial, decrease blood } \\
\text { cholesterol and anti-inflammatory }[31,32] \text {. }\end{array}$ \\
\hline 13 & 16.293 & n-Hexadecanoic acid & C16H32O2 & 256 & 4.40 & $\begin{array}{l}\text { Antibacterial, antifungal activity and anti- } \\
\text { inflammatory }[33,34] .\end{array}$ \\
\hline 14 & 18.078 & $\begin{array}{l}9,12-\text { Octadecadienoic acid }(Z, Z)-\text {, } \\
\text { methyl ester }\end{array}$ & $\mathrm{C}_{19} \mathrm{H}_{34} \mathrm{O}_{2}$ & 294.4721 & 2.08 & $\begin{array}{l}\text { Antiinflammatory, insectifuge, anticancer, } \\
\text { hepatoprotective, antimicrobial, antieczemic, }\end{array}$ \\
\hline
\end{tabular}


Momoh et al.; ARRB, 35(12): 183-197, 2020; Article no.ARRB.60062

\begin{tabular}{|c|c|c|c|c|c|c|}
\hline $\begin{array}{l}\text { PK } \\
\text { no }\end{array}$ & $\begin{array}{l}\text { Retention } \\
\text { time }\end{array}$ & Name of compound & $\begin{array}{l}\text { Molecular } \\
\text { formulae }\end{array}$ & $\begin{array}{l}\text { Molecular } \\
\text { weight } \\
\text { (g/mol) }\end{array}$ & $\begin{array}{l}\text { Peak } \\
\text { area }(\%)\end{array}$ & Activity \\
\hline $\begin{array}{l}15 \\
16\end{array}$ & $\begin{array}{l}18.176 \\
18.382\end{array}$ & $\begin{array}{l}\text { Cyclooctene, 3-ethenyl- } \\
\text { Phytol }\end{array}$ & $\begin{array}{l}\mathrm{C}_{10} \mathrm{H}_{16} \\
\mathrm{C}_{20} \mathrm{H}_{40} \mathrm{O}\end{array}$ & $\begin{array}{l}136.23 \\
296.5\end{array}$ & $\begin{array}{l}5.74 \\
10.16\end{array}$ & $\begin{array}{l}\text { antihistaminic, hypocholesterolemic, [35,36]. } \\
\text { NF } \\
\text { Anticancer [31], Antimicrobial, anticancer, anti } \\
\text { inflamatory, diuretic [37]. }\end{array}$ \\
\hline 17 & 18.628 & $\begin{array}{l}\text { Heptadecanoic acid, 16-methyl-, } \\
\text { methyl ester }\end{array}$ & $\mathrm{C}_{19} \mathrm{H}_{38} \mathrm{O}_{2}$ & 298.5038 & 1.98 & Used against skin cancer protein [38]. \\
\hline 18 & 19.040 & 9,12-Octadecadienoic acid (Z,Z)- & $\mathrm{C}_{18} \mathrm{H}_{32} \mathrm{O}_{2}$ & 280.44 & 2.16 & $\begin{array}{l}\text { hepatoprotective, hypocholesterolemic, anti- } \\
\text { arthritic, anti-inflammatory, anti-histaminic and } \\
\text { nematicidal activities [39]. }\end{array}$ \\
\hline 19 & 22.496 & $\begin{array}{l}\text { 4,8,12,16-Tetramethylheptadecan-4- } \\
\text { olide }\end{array}$ & $\mathrm{C}_{21} \mathrm{H}_{40} \mathrm{O}_{2}$ & 324.5 & 2.00 & NF \\
\hline 20 & 23.051 & $\begin{array}{l}(2 \mathrm{E}, 6 \mathrm{E})-3,7,11-\text { Trimethyldodeca-2,6 } \\
\text {,10-trienyl propionate }\end{array}$ & $\mathrm{C}_{18} \mathrm{H}_{30} \mathrm{O}_{2}$ & 278.4296 & 1.15 & NF \\
\hline 21 & 25.151 & 1-Chloroeicosane & $\mathrm{C}_{20} \mathrm{H}_{41} \mathrm{Cl}$ & 317 & 1.76 & NF \\
\hline 22 & 26.026 & Mono(2-ethylhexyl) phthalate & $\mathrm{C}_{16} \mathrm{H}_{22} \mathrm{O}_{4}$ & 278.3435 & 0.87 & Stimulates androgen production [40]. \\
\hline 23 & 28.687 & Ethanol, 2-(dodecyloxy)- & $\mathrm{C}_{14} \mathrm{H}_{30} \mathrm{O}_{2}$ & 230.3868 & 1.15 & NF \\
\hline 24 & 31.010 & Squalene & $\mathrm{C} 30 \mathrm{H} 50$ & 410.7 & 27.28 & $\begin{array}{l}\text { Antioxidant, antibacterial, cancer preventive, } \\
\text { antitumor, cancer preventive, chemo preventive, } \\
\text { immunostimulant and lipoxygenase-inhibitor } \\
{[41,42] \text {. }}\end{array}$ \\
\hline 25 & 32.698 & Carbonic acid, decyl tetradecyl ester & $\mathrm{C}_{25} \mathrm{H}_{50} \mathrm{O}_{3}$ & 398.6627 & 3.04 & NF \\
\hline 26 & 33.699 & Delta.-Tocopherol & $\mathrm{C}_{27} \mathrm{H}_{46} \mathrm{O}_{2}$ & 402.7 & 1.34 & $\begin{array}{l}\text { antiinflammatory, dermatologic, antisecretoric, } \\
\text { antiacne, antiprotozoal } \\
\text { (Leishmania) and Bone formation stimulant [29], } \\
\text { Antioxidant activity, effective against asthma, } \\
\text { allergies, diabetes, atherosclerosis, cancer, } \\
\text { ageing, arthritis and cataracts [43]. }\end{array}$ \\
\hline
\end{tabular}


that saponins, flavonoids, tannins and other secondary metabolites in plant may play some roles in the inhibition of malaria parasites in infected animals [52,53]. Flavonoids have been reported to have significant in-vitro antimalarial activity against $P$. falciparum [54] and this may be responsible for the antimalarial activities exhibited by $C$. papaya methanolic leaf extract.

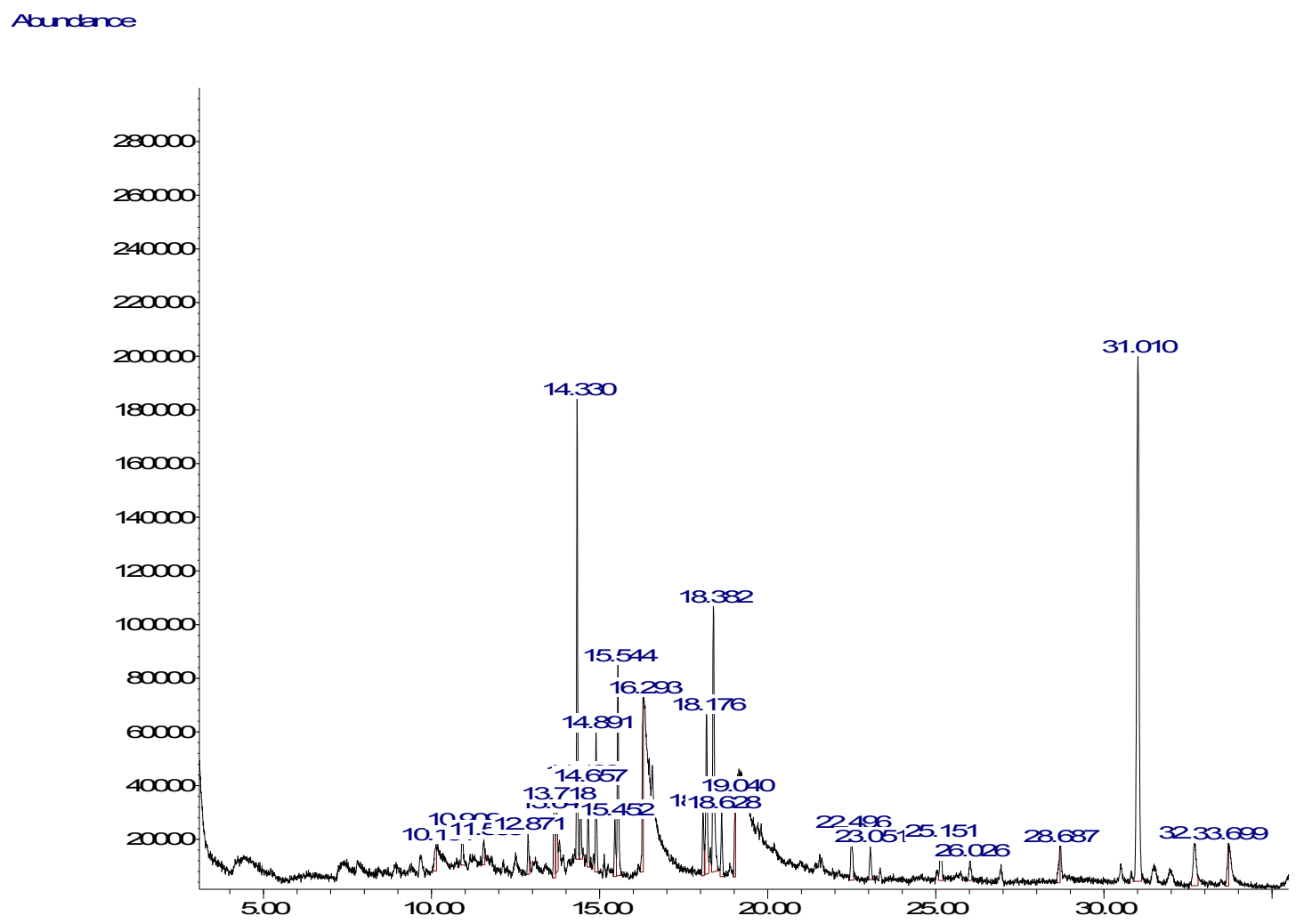

Tirre $\rightarrow$

Fig. 1. Gas chromatography-mass spectrometry chromatogram of Carica papaya methanolic leaf extract
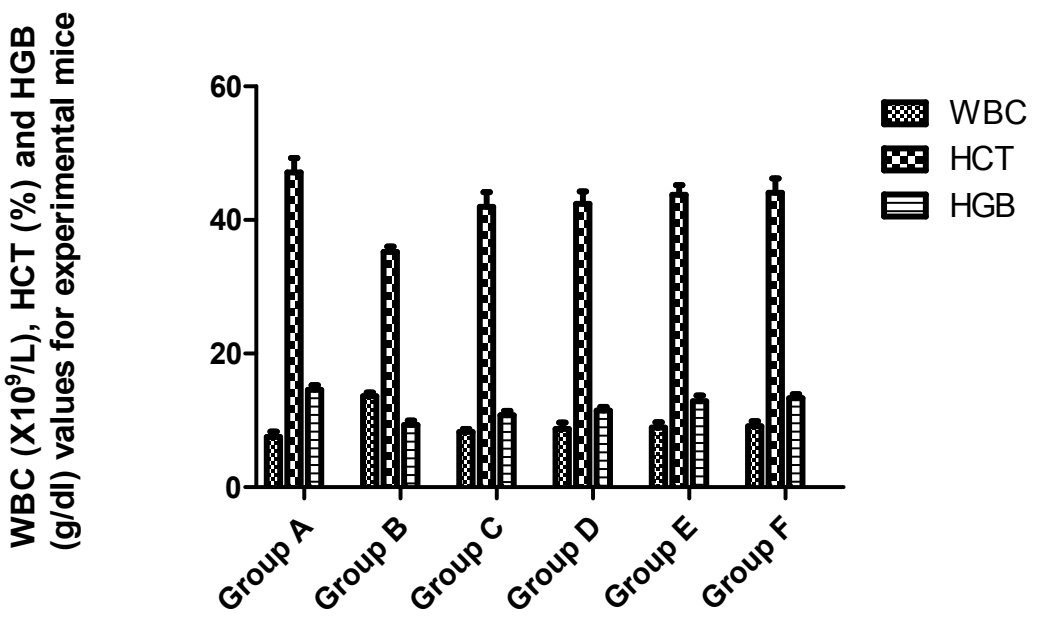

Fig. 2. Effect of methanolic leaf extract of $C$.papaya on WBC, HCT and HGB values in mice infected with P.berghei NK 65 
Table 3. The qualitative phytochemical constituents of methanolic leaf extract of Carica papaya

\begin{tabular}{ll}
\hline Phytochemical constituent & Inference \\
\hline Tannins & + \\
Flavonoids & + \\
Alkaloids & + \\
Cardiac glycosides & + \\
Reducing sugar & + \\
Anthraquinone & + \\
Terpenoids & + \\
Saponins & + \\
Phenolic compounds & + \\
\hline
\end{tabular}

Table 4. Curative test showing the effect of Chloroquine, Arthesunate, and different concentration of methanolic leaf extract of Carica papaya against Plasmodium berghei NK65 induced Swiss mice

\begin{tabular}{llll}
\hline Group & $\begin{array}{l}\text { Dose } \\
(\mathbf{m g} / \mathbf{k g})\end{array}$ & $\begin{array}{l}\text { Mean parasitemia } \\
\text { density (D10) }\end{array}$ & \% Suppression \\
\hline $\mathrm{A}$ & - & - & $\mathrm{NIL}$ \\
$\mathrm{B}$ & - & $12,571.63$ & $\mathrm{Nil}$ \\
$\mathrm{C}$ & 10 & $897.52^{*}$ & $92.86^{*}$ \\
$\mathrm{D}$ & 10 & $1,172.73^{*}$ & $90.67^{*}$ \\
$\mathrm{E}$ & 400 & $5,436.31^{*}$ & $56.76^{*}$ \\
$\mathrm{~F}$ & 600 & $3,076.82^{*}$ & $75.53^{*}$ \\
\hline \multicolumn{4}{r}{ The values are expressed in mean \pm SD for six mice in each group. *indicate significant difference from negative } \\
\multicolumn{4}{r}{ control at $P<0.05$}
\end{tabular}
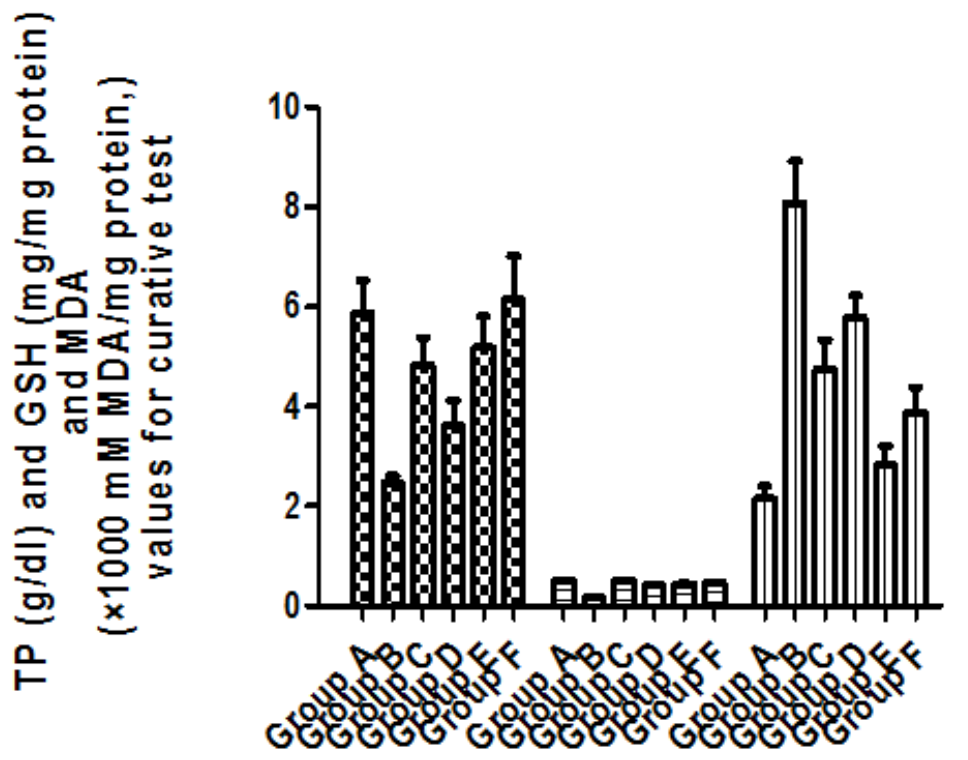

Total protein (TP)

Eeduced glutathione GSH) III MDA

Fig. 3. Effect of methanolic leaf extract of $C$. papaya on TP, GSH and MDA values in mice infected with $P$. berghei NK 65 


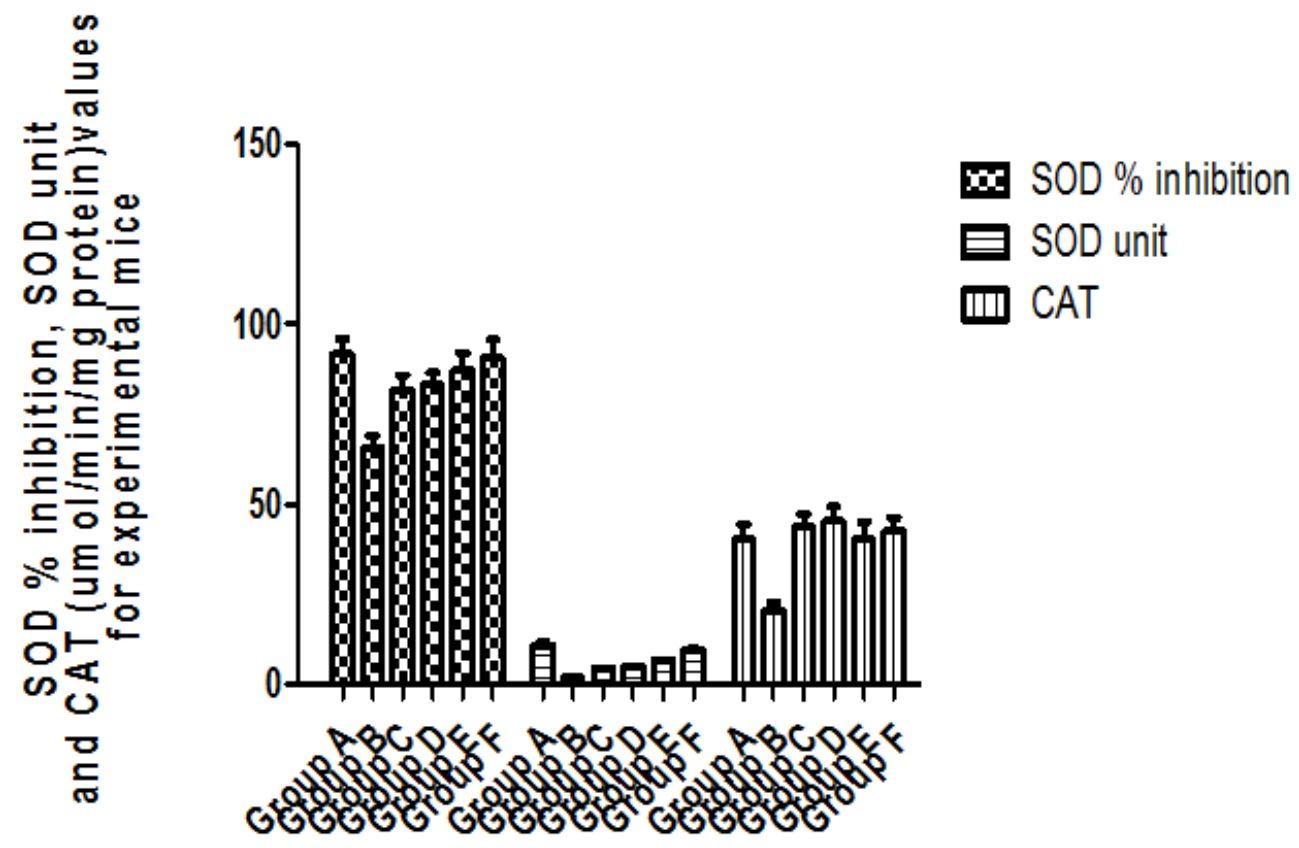

Fig. 4. Effect of methanolic leaf extract of $C$. papaya on SOD \% inhibition, SOD unit and CAT values in mice infected with $P$. berghei NK 65

The study shows clearly that 400 and $600 \mathrm{mg} / \mathrm{kg}$ body weight of $C$. papaya methanolic leaf extracts showed a dose dependent and progressive reduction in parasitemia with time observed during curative test. Other studies showed similar antiplasmodial activities of the plant. Melariri et al. [5] study showed that antiplasmodial activity was observed in the ethyl acetate crude extract of $C$. papaya against $P$. falciparum [5]. Okpe et al. [55] study showed that individual administration of aqueous leaf extract of C. papaya, $V$. amygdalina, and the combination of both plants significantly $(P<0.05)$ decreased parasite load in mice induce with $P$. berghei and enhanced their survival. Longdet and Emmanuel Adoga, [49] study shows that the average daily parasitemia of infected mice treated with chloroquine, $400 \mathrm{mg} / \mathrm{kg}$ and 200 $\mathrm{mg} / \mathrm{kg}$ leaf extract of Carica papaya respectively significantly $(P<0.05)$ reduced when compared with control group. However, they did not observe any significant $(p>0.05)$ difference in the level of the parasitemia in infected mice treated with $100 \mathrm{mg} / \mathrm{kg}$ body weight of Carica papaya leaf extract when compared with the control group. Another study showed that methanolic extract of C. papaya at $200 \mathrm{mg} / \mathrm{kg}$ body weight gave significant suppression $(p<0.05)$ of parasitemia following five days administration in established infection [56]. White blood cell components fight against invading pathogens and are usually mobilized in large number. In this study, the components of the WBC increased in correspondence to the increased parasite load of the Swiss mice after infection, which decreased after treatment with the chloroquine, artesunate, 400 and $600 \mathrm{mg} / \mathrm{kg}$ body weight of methanolic leaf extract of $C$. papaya. The reduction in the HCT and HGB in the untreated group could be due to the destruction of the RBCs by the parasite as it is known to cause anemia but the improvement in the HCT and HGB in the treated groups showed that the methanolic leaf of $C$. papaya has antianemic properties and could improve hemopoietic system. Momoh et al. [14] study shows that methanolic leaf extract of Morinda lucida significantly $((P<0.05)$ increase HCT, HGB but WBC count decreased significantly $(P<0.05)$ in Swiss mice induced with Plasmodium berghei NK65. Liver oxidative damage in mice infected with $P$. berghei was detected through significant $(P<0.05)$ elevation of malondialdehyde (MDA), decrease in total protein (TP), superoxide dismutase (SOD) \% inhibition, SOD unit, reduced glutathione (GSH) and catalase (CAT) in the negative control group mice (group B) when compared to other mice in other group. The extract and the standard drugs significantly $(P<0.05)$ help in the restoration of hepatic TP, SOD \% inhibition, SOD unit, GSH and CAT in the treated mice. The levels of hepatic MDA values was significantly $(P<0.05)$ 
reduced in the treated group mice compared to the untreated group mice. Study has shown that MDA level was significantly $(P<0.05)$ decreased and an increase in the total protein, catalase, SOD \% inhibition, SOD unit and Vitamin A levels in the liver homogenate of animals treated with chloroquine, artesunate and extract of $M$. lucida were obtained when compared to the untreated mice [14]. The protective properties of the methanolic leaf extract of $C$. papaya on hepatic tissues through reinstating the normal levels of the oxidative stress markers and impeding the progression of hepatic fibrosis upon $P$. berghei induced hepatic damage indicate that the plant is good for consumption and reduces oxidative stress in the infected Swiss mice.

\section{CONCLUSION}

The study shows that methanolic leaf extract of Carica papaya possess antimalarial activity in Swiss mice infected with Plasmodium berghei NK 65.

\section{ETHICAL APPROVAL}

The mice were used in accordance with $\mathrm{NIH}$ Guide for the care and use of laboratory animals; NIH Publication revised (1985) NIPRD Standard Operation Procedures (SOPs).

\section{ACKNOWLEDGEMENTS}

The authors acknowledge the assistance rendered by Miss Salako Mojisola Bukola when carrying out laboratory analyses.

\section{COMPETING INTERESTS}

Authors have declared that no competing interests exist.

\section{REFERENCES}

1. Kato N, Comer E, Sakata-Kato et al. Diversity-oriented synthesis yields novel multistage antimalarial inhibitors. Nature. 2016;538(7625):344-349.

2. Hoareau I, Da Silva EJ. Medicinal plants: A re-emerging health aid. Electronic Journal of Biotechnology. 1999;2(2):56-69.

3. Owusu-Agyei S, Asante KP, Adjuik et al. Epidemiology of malaria in the forest-savanna transitional zone of Ghana. Malaria Journal. 2009;8(1), article 220.
4. Ong HC, Ruzalila BN, Milow P. Traditional knowledge of medicinal plants among the malay villagers in Kampung Tanjung Sabtu, Terengganu, Malaysia. Indian Journal of Traditional Knowledge. 2011; 10(3):460-465.

5. Melariri P, Campbell W, Etusim P, Smith P. Antiplasmodial properties and bioassayguided fractionation of ethyl acetate extracts from Carica papaya leaves. Journal of Parasitology Research. 2011;2011:Article ID 104954, 7 pages.

6. Yusha'u M, Onourah FC, Murtala Y. Invitro sensitivity pattern of some urinary tract isolated to Carica papaya extracts. Bayero Journal of Pure and Applied Sciences. 2009;2(2):75-78.

7. Otsuki N, Dang NH, Kumagai E, Kondo A, Iwata S, Morimoto C. Aqueous extract of Carica papaya leaves exhibits anti-tumor activity and immuno modulatory effects. Journal of Ethnopharmacology. 2010; 127(3):760-767.

8. Murukami A, Ohigashi $\mathrm{H}$, Koshimizu K. Possible antitumour promoting properties of traditional Thai food items and some of their active constituents. Asia Pasific Journal of Clinical Nutrition. 1994;3:185191.

9. Canini A, Alesiani D, D'Arcangelo G, Tagliatesta P. Gas chromatography-mass spectrometry analysis of phenolic compounds from Carica papaya L. leaf. Journal of Food Composition and Analysis. 2007;20(7):584-590.

10. Indran M, Mahmood AA, Kuppusamy UR. Protective effect of Carica papaya $L$ leaf extract against alcohol induced acute gastric damage and blood oxidative stress in rats. West Indian Medical Journal. 2008;57(4):323-326,

11. Mahmood AA, Siddiq K, Salmah I. Wound healing acivity of Carica papaya $L$. aqueous leaf extract rats. Journal of Molecular and Advance Sciences. 2005;1:398-401.

12. Osato JA, Santiago LA, Remo GM, Cuadra MS, Mori A. Antimicrobial and antioxidant activities of unripe Papaya. Life Sciences. 1993;53(17):1383-1389.

13. Krishna KL, Paridhavi M, Patel JA. Review on nutritional, medicinal and pharmacological properties of Papaya (Carica papaya Linn.). Natural Product Radiance. 2008;7(4):364-373.

14. Momoh JO, Damazio OA, Ajetunmobi AO, Babalola AO, Adekunle OM, Busari NO, 
Musa AA. Phytochemical analysis and antiplasmodial (curative) activities of methanolic leaf extract of Morinda lucida (Ewe Oruwo) in male Swiss mice infected with Plasmodium berghei NK65. IJTDH. 2019;37(1):1-13. Article no.IJTDH.47956. DOI: 10.9734/IJTDH/2019/v37i130156

15. Sofowora A. Medicinal plants and traditional medicines in Africa Spectrum Book Ltd. Ibadan, Nigeria. 1993;289.

16. Trease GE, Evans WC. Pharmacognsy. 11th edition. London: Brailliar Tiridel Can Macmillian Publishers. 1986;60-75.

17. NIH. Guide for the car and use of Laboratory animal (Revised). Washington: NIH Publication. 1985;8:3-23.

18. Momoh J, Longe AO. Phenolic contents, in-vitro antioxidant activity and in-vivo antiplasmodial activity of methanolic leaf extract of Azadirachta indica (dongoyaro) and its effect on some biochemical parameters in Swiss albino mice infected with Plasmodium berghei NK 65. International Journal of Current Research. 2015;7(3):13769-13778.

19. Akuodor GC, Usman MI, Ugwu TC, Akpan JL, Ghasi SI, Osunkwo UA. In vivo schizontal activity of ethanolic leaf extract of Gongronema latifolium on Plasmodium berghei berghei in mice. Ibnosina Journal of Medical and Biomedical Science. 2010;2(3):118-124.

20. Chandel S, Bagai U. Antiplasmodial activity of Ajuga bracteosa against Plasmodial berghei infected BALB/c mice. Indian Journal of Medical Research. 2010;131:440-444.

21. Rukkumani $\mathrm{R}$, Aruna K, Varma PS, Rajasekaran KN, Menon VP. Comparative effects of Curcumin and an analog of Curcumin on alcohol and PUFA induced oxidative stress. Journal of Pharmacy and Pharmaceutical Science. 2004;7(2):274283.

22. Jiang ZY, Hunt JY, Wolff SP. Detection of lipid hydroperoxides using the 'Fox method. Analytical Biochemistry. 1992;202:384-389.

23. Zou GL, Gui XF, Zhong XL, Zhu YF. Improvements in pyrogallol autoxidation method for the determination of SOD activity. Progress in Biochemistry and Biophysics. 1986;4:71-73.

24. Farina $M$, Preeti $B$, Neelam $P$. Phytochemical evaluation, antimicrobial activity, and determination of bioactive components from leaves of Aegle marmelos. Bio Med Research International. 2014;2014:

ArticlelD497606:11.

Available:http://dx.doi.org/10.1155/2014/49 7606

25. Haider $\mathrm{MH}$, Imad $\mathrm{HH}$, Omar Al. Antimicrobial activity and spectral chemical analysis of methanolic leaves extract of Adiantum capillus-veneris using GC-MS and FT-IR Spectroscopy. International Journal of Pharmacognosy and Phytochemical Research. 2016;8(3): 369-385.

26. Hunyadi A, Veres K, Danko B, Kele Z, Weber E, Hetenyi A, Hsieh TJ. In vitro antidiabetic activity and chemical characterization of an apolar fraction of Morus alba leaf water extract. Phytotherapy Research. 2012;1-5.

27. Jayawardenaa TU, HS, Sanjeewaa KKA, Kima SY, Rhob JR, Jeec Y, Ahnd G, Jeona YJ. Sargassum horneri and isolated 6-hydroxy-4,4,7a-trimethyl-

5,6,7,7atetrahydrobenzofuran-2(4H)-one (HTT); LPS-induced inflammation attenuation via suppressing NF-kB, MAPK and oxidative stress through Nrf2/HO-1 pathways in RAW 264.7 macrophages. Algal Research. 2019;40 101513.

DOI: org/10.1016/j.algal.2019.101513

28. Venkata RB, Samuel IA, Pardha SM, Narashimha RB, Naga VKA, Sudhakar M, Radhakrishnan TM. Antibacterial, antioxidant activity and GS-MS analysis of Eupatorium odoratum. Asian J Pharm Clin Res. 2012;5(2):99-106.

29. Dnan A, Nazim UC, ATM, Mostafa K, Obyedul KAz, Arkajyoti $P$, Shaikh BU, James WB, Mohammad OF, Cheol HP, Dong HC. Investigation of the biological activities and characterization of bioactive constituents of Ophiorrhiza rugosa var. prostrata (D.Don) \& Mondal Leaves through In Vivo, In Vitro, and In Silico Approaches. Molecules. 2019;24:1367. DOI: 10.3390/molecules24071367

30. Arora S, Kumar G, Meena S. Screening and evaluation of bioactive components of Cenchrus ciliaris I. by GC-MS analysis. Int. Res. J. Pharm. 2017;8(6). DOI: $10.7897 / 2230-8407.08699$

31. Akpuaka A, Ekwenchi MM, Dashak DA, Dildar A. Biological activities of characterized isolates of $n$-Hexane extract of Azadirachta indica A. Juss (Neem) Leaves. New York Sci. J. 2013;6(6):119124. 
32. Hema R, Kumaravel S, Alagusundaram. GC-MS determination of bioactive components of Murraya koenigii. Journal of American Science. 2011;7(1):80-82.

33. Ogunlesi M, Okiei W, Osibote EA. Analysis of the essential oil from the leaves of Sesamum radiatum, a potential medication for male infertility factor, by gas chromatography - mass spectrometry. African Journal of Biotechnology. 2010;9(7):1060-1067.

Available:http://www.academicjournals.org/ AJB. ISSN 1684-5315 (c) 2010 Academic Journals

34. Aparna V, Dileep KV, Mandal PK, Karthe $\mathrm{P}$, Sadasivan C, Haridas M. Antiinflammatory property of $\mathrm{n}$-hexadecanoic acid: Structural evidence and kinetic assessment. Chem. Biol. Drug Des. 2012;80(3):434-439.

DOI: $10.1111 / \mathrm{j} .1747-0285.2012 .01418 . x$

35. Longe AO, Momoh JO, Asoro II. Gas Chromatography-Mass Spectrometry (GCMS) analysis of phytocomponents in the root, stem bark and leaf of Vernonia amygdalina. World Journal of Pharmaceutical Research. 2017;6(2):3549.

36. Adeyemi MA, Ekunseitan DA, Abiola SS, Dipeolu MA, Egbeyale LT, Sogunle OM. Phytochemical analysis and GC-MS determination of Lagenaria breviflora $R$. fruit. IJPPR. 2017;9(7):1045-1050

37. Igwe KK, Okaforl PN, ljeh I. GC-MS analysis of phytocomponents in Vernonia amygdalina. Del leaves and its contractile potential in mammary tissue in female albino Wistar rats. 2015; (IOSR-JAVS) eISSN: 2319-2380, p-ISSN: 2319-2372. 2015;8(11)(Ver. I)25-30.

DOI: $10.9790 / 2380-081112530$

38. Aruna LH, Amarvani PK, Ramesh LL. Bioactive compounds investigation from methanol bark extract of Pterocarpus marsupium using GC-MS analysis. IJPQA. 2017;8(3).

39. Sermakkani M, Thangapandian V. GC-MS analysis of Cassia italic a leaf methanol extract. Asian J. Pharm. Clin. Res. 2012;5(2):90-94.

40. Iuliia S, Olle S, Konstantin S. Mono-2ethylhexyl phthalate stimulates androgen production but suppresses mitochondrial function in mouse leydig cells with different steroidogenic potential. Toxicological sciences. 2015;145(1):149-156.

DOI: $10.1093 /$ toxsci/kfv042
41. Ruba AA, Mohan VR. GC-MS analysis of bioactive compounds present in the whole plant of Andrographis echioides (I) Nees (Acanthaeceae). Ejbps. 2014;1(3):443452.

42. Reddy LH, Couvreur P. Squalene: A natural triterpene for use in disease management and therapy. Advanced Drug Delivery Reviews. 2009;61:14121426.

43. Rizvi S, Raza ST, Ahmed F, Ahmad A, Abbas $S$, Mahdi $F$. The role of Vitamin $E$ in human health and some diseases. Sultan Qaboos Univ Med J. 2014;14(2):e157e165.

44. Evans WC, Evans T. Pharmalognosy (15 edition) W.B Saunders company LTD. London. 2002;191-393.

45. Fadare OA, Durosimi OM, Fadare $\mathrm{R}$, Izevbekhai OU, Isaac OA, Obafemi CA. ATR-FTIR and HPLC spectroscopic studies and evaluation of mineral content of Carica papaya leaves and flowers. JP. 2015;14(1):1.

46. Maisarah AM, Asmah R, Fauziah O. Proximate analysis, antioxidant and antiproliferative activities of different parts of Carica papaya. J Nutr Food Sci. 2014;(4):267.

DOI: $10.4172 / 21559600.1000267$

47. Ezhilan BP, Neelamegam R. GC-MS analysis of phytocomponents in the ethanol extracts of Polygonum Chinense L. Pharmacognosy Res. 2012;4(1):11-4. Available:https://doi.org/10.4103/09748490.91028 PMID:22224055

PMCID:PMC3250032

48. Ogunlesi M, Okiei W, Ofor E, Osibote AE. Analysis of the essential oil from the dried leaves of Euphorbia hirta Linn (Euphorbiaceae), a potential medication for asthma. Afr J Biotechnol. 2009; 8:7042-50. DOI: 10.5897/AJB09.1324

49. Longdet IY, Adoga EA. Effect of methanolic leaf extract of Carica papaya on Plasmodium berghei Infection in Albino mice. EJMP. 2017;20(1):1-7. Article no.EJMP.34698. ISSN: 2231-0894, NLM ID: 101583475.

50. Biu AA, Buratai LB, Ahmad AA, Hambali IU, Ngulde SI, Zakariah M, Lawal JR. Phytochemistry, toxicity and efficacy of crude aqueous extract of Carica papaya leaf against Trypanosoma brucei. Bangl. J.Vet. Med. 2016;14(1):99-102. 
51. Akhila S, Vijayalakshmi NG. Phytochemical studies on Carica papaya leaf juice. IJPSR. 2015;6(2):880-883.

52. Igile GO, Oleszek W, Jurzysta M, Burda S, Fafunso M, Fasanmade AA. Flavonoids from Vernonia amygdalina and their antioxidant activities. Journal of Agricultural and Food Chemistry. 1994; 42(11):2445-2448.

53. Udensi E, ljeh I, Ogbonna U. Effect of traditional processing on the phytochemical and nutrient composition of some local Nigerian leafy vegetables. Journal of Science and Technology. 2002;8:37-40.

54. Chanphen $\mathrm{R}$, Thebtaranonth $\mathrm{Y}$, Wanauppathamkul S, Yuthavong Y. Antimalarial principles from Artemisia indica. Journal of Natural Products. 1998;61:1146-1147.

55. Okpe O, Habila N, Ikwebe J, Upev VA, Okoduwa SIR, Isaac OT. Antimalarial Potential of Carica papaya and Vernonia amygdalina in mice infected with Plasmodium berghei Volume. 2016;Article ID 8738972, 6 pages

Available:http://dx.doi.org/10.1155/2016/87 38972

56. Arise RO, Malomo SO Lawal MM. Comparative antimalarial and toxicological effects of artemisinin with methanolic extract of Carica papaya leaves and bark of Alstonia broonai in animal models. Advances in Natural and Applied Sciences. 2012;6(2):116-123.

(c) 2020 Momoh et al.; This is an Open Access article distributed under the terms of the Creative Commons Attribution License (http://creativecommons.org/licenses/by/4.0), which permits unrestricted use, distribution, and reproduction in any medium, provided the original work is properly cited.

Peer-review history:

The peer review history for this paper can be accessed here: http://www.sdiarticle4.com/review-history/60062 